\title{
Effectiveness of sealants on incipient cavitaded lesions
}

\section{Introduction}

Dental caries remains one of the most prevalent diseases among all other diseases related to man, being considered a challenge to global public health. ${ }^{1,2}$ To understand this panorama, it is necessary to perform a situational diagnosis, i.e., to relate individuals to the environment in which they are inserted, taking into consideration numerous causes such as: daily habits, culture, ethnic/racial factors, psychological factors and socioeconomic status. ${ }^{3-5}$ From this, it is possible to implement actions that could reverse the current situation, performing basic attention care to oral health, giving greater emphasis to the promotion and prevention of oral health of more vulnerable groups. ${ }^{6}$ Therefore, greater knowledge is needed about the use of techniques and materials that act by preventing and controlling the caries. ${ }^{7,8}$ In the past the presence of radiolucency at any depth and small cavitations seen in clinical examination, even if restricted to the enamel, were an indicative for an invasive restorative treatment. ${ }^{8}$ Currently, the development of new techniques has enabled the realization of a more conservative treatment with minimal intervention, by means of healthy dental structure preservation. ${ }^{8,9}$ Thus, sealants constitute a widely used method in the control of carious lesions, as they form a mechanical barrier, preventing contact of the biofilm with the dental surface ${ }^{8-10}$ Although there are several studies on the action of sealants, there are still numerous doubts regarding the use of these materials. With the intention of clarifying the efficiency and effectiveness of the sealants in carious cavities without pulpal involvement, the present research of systematic review and meta-analysis was made.

\section{Material and methods}

The selection of articles used in the study was performed in two phases:

\section{Abstracts and titles were selected}

2. The full texts of the selected titles were obtained and read to determine the final sample set.

\section{Research strategies}

The databases used for the tracking of articles were PubMed, Web of Science, the Cochrane plus Library, Single (Grey Literature Information System) and Lilacs. To identify studies included or considered for this review, a research strategy was developed for the electronic databases, using keywords from the list of Health Sciences Descriptors (DeCS) and from Medical Subject Headings (MeSH) and their combinations until September 30, 2017. The following keywords were used: "dental caries", "proximal caries", "proximal caries", "proximal lesions", "enamel caries", 'dentin caries", "caries lesions", 'tooth demineralization', 'occlusal caries", "decay", "therapy", "resin infiltration technique", "resin infiltration", "caries infiltration", "infiltration", "nonoperative treatment", "micro-invasive treatment", "bitewing", "radiograph", "pit and fissure sealants", "infiltrant", "adhesives", "adhesives system", "dental cements", "composite resins", "glass ionomer", "ionomer resin", "ionomer resin modified glass", "formation of gaps", "resin cements", "resins", "synthetic", "hydrochloric acid", "low viscosity resin", "occlusal
Volume 9 Issue 3 - 2018

\author{
Sabrina Hundertmarch Paz,' Dióger dos \\ Santos Paz,' Valéria Silva Candido Brizon,' \\ Francisco Carlos Groppo, ${ }^{2}$ Antonio Carlos \\ Pereiral \\ 'Department of Social Dentistry, State University of Campinas, \\ Brazil \\ ${ }^{2}$ Department of Physiological Sciences, State University of \\ Campinas, Brazil
}

Correspondence: Sabrina Hundertmarch Paz, Department of Social Dentistry, State University of Campinas, Av.Bompland, 1638. Bairro Centro, São Borja, RS CEP: 97670-000, Tel 55 999662590,Email sabrina.paz@iffarroupilha.edu.br

Received: April 25, 2018 | Published: June 05, 2018

sealant", "occlusal glass".

\section{Inclusion criteria}

Randomized controlled trials (RCT) or controlled clinical trials (CCT) with at least 12 months of monitoring were included. In accordance with the population, children and adolescents aged from 5 to 14 years with carious cavitated lesions in deciduous and permanent teeth were included in the study. As for the intervention, the use of sealants in carious cavities without pulpal involvement constituted the focus of the study. Regarding comparisons, the intervention under investigation should be compared to control groups composed of a different material or a different technique or even a placebo and, finally, as a measure of results, preferably bitewing radiographs should be used to verify the control of caries.

\section{Exclusion criteria}

Editorials letters, pilot studies, historical commentary, animal studies, in vitro studies, cohort studies, observational studies and descriptive studies, such as case reports and case series were excluded.

\section{Selection of studies}

The initial research was conducted by two independent researchers (SHP, DP), which located and selected the articles. The selection of the articles based on title and abstract was held independently. After reading the title of the article, the researchers selected it or not for the systematic review. If the article did not meet the inclusion criteria, the title was excluded. If the title of the article did not provide sufficient information to either select it or exclude it, the researchers selected or excluded the study by its abstract. If there was a repetition of the same study, the copy was excluded.

After a systematic search and selection of the articles, a first consensus meeting to address questions and disagreements between researchers was held, now involving a third researcher with experience in systematic reviews (VSCB). 


\section{Data gathering}

The next step was the search and full reading of the selected articles and subsequent assessment for them to be included in the sample. Each researcher filled a standardized form in Microsoft Excel (2008), with the following information: author, year and country where the study was conducted; type of study, sample, sample's age, sex, type of intervention taken with the test group, type of intervention taken with the control group, diagnostic criteria of inclusion, measurement of results through bitewing radiographs, materials used in the intervention and control groups, return visits for evaluations and monitoring time (Table 1). The reference lists of the selected articles were also checked independently by two researchers who continued with the search, to identify studies with potential relevance which was not found in the electronic search, however there was no additional inclusion of studies. A second consensus meeting between the three researchers to address questions and disagreements between the articles read and for filling out the forms was held. The studies that met the established criteria were considered in the final analysis. Possible disagreements throughout the process were resolved by consensus (Figure 1). The quality of the articles was evaluated through the Quality assessment tool for quantitative studies by two independent evaluators, and disagreements were resolved by consensus. This scale was suggested by Jackson \& Waters ${ }^{11}$ for evaluation of systematic reviews of health promotion and public health interventions; in addition to randomized controlled trials, quasi-experimental studies and non-controlled studies. ${ }^{12}$ The scale evaluates articles in six different parameters: selection bias, forms of study, confusion factors, blinding, collection methods and sample losses. The final score 1 classifies the study as strong, 2 as moderate, and 3 as weak. The risk of bias is evaluated according to the result of the evaluation of the quality; the stronger the study, the lower the risk of bias; and the weaker it is, the greater the risk of bias. The final score 1 classifies a low risk of bias, 2 as moderate and 3 as high risk.

Table I Comparison between studies selected for this review

\begin{tabular}{|c|c|c|c|c|c|c|c|c|c|c|c|}
\hline \multirow[b]{2}{*}{$\begin{array}{l}\text { Author(s) } \\
\text { (Country, } \\
\text { year) }\end{array}$} & \multirow[b]{2}{*}{$\begin{array}{l}\text { Type } \\
\text { of } \\
\text { study }\end{array}$} & \multicolumn{3}{|l|}{ Sample } & \multicolumn{4}{|c|}{ Intervention groups } & \multirow[b]{2}{*}{$\begin{array}{l}\text { Inclusion } \\
\text { criteria }\end{array}$} & \multirow{2}{*}{$\begin{array}{l}\text { Measure } \\
\text { of results } \\
\text { (bitewing } \\
\text { radiogra- } \\
\text { phy) }\end{array}$} & \multirow{2}{*}{$\begin{array}{l}\text { Return } \\
\text { visits/Time } \\
\text { of monito- } \\
\text { ring }\end{array}$} \\
\hline & & $\begin{array}{l}\text { Individual } \\
\text { (Teeth) }\end{array}$ & $\begin{array}{l}\text { Age } \\
\text { (average) }\end{array}$ & Sex & $\begin{array}{l}\text { Group I } \\
\text { Individual } \\
\text { (Teeth) }\end{array}$ & $\begin{array}{l}\text { Group } 2 \\
\text { Individual } \\
\text { (Teeth) }\end{array}$ & $\begin{array}{l}\text { Group } 3 \\
\text { Individual } \\
\text { (Teeth) }\end{array}$ & $\begin{array}{l}\text { Group } 4 \\
\text { Individual } \\
\text { (Teeth) }\end{array}$ & & & \\
\hline $\begin{array}{l}\text { Flório et } \\
\text { al. }^{16}\end{array}$ & RCT & 34 & DNC (6) & $M / F$ & $\begin{array}{l}12(35) \\
\text { Vitremer }{ }^{\circledR} \\
\text { (reapplied } \\
\text { in cases of } \\
\text { losses) }\end{array}$ & $\begin{array}{l}\text { I I (36) } \\
\text { Duraphat }{ }^{\circledR} \\
\text { (reapplied } \\
\text { every } 6 \\
\text { months) }\end{array}$ & $\begin{array}{l}\text { II (37) } \\
\text { Control- } \\
\text { (information } \\
\text { about oral } \\
\text { health and } \\
\text { training for } \\
\text { the control } \\
\text { of plaque/ } \\
\text { visit) }\end{array}$ & & $\begin{array}{l}\text { Children from } \\
\text { kindergartens } \\
\text { and schools } \\
\text { of Piracicaba } \\
\text { which } \\
\text { had caries } \\
\text { restricted to } \\
\text { the enamel } \\
\text { and without } \\
\text { hypoplasia, } \\
\text { sealings or } \\
\text { restorations }\end{array}$ & $\begin{array}{l}\text { Direct digital } \\
\text { radiography. }\end{array}$ & $\begin{array}{l}\text { Every } 3 \\
\text { months } \\
\text { up to } 12 \\
\text { months }\end{array}$ \\
\hline $\begin{array}{l}\text { Oulis et } \\
\text { al. }{ }^{18}\end{array}$ & RCT & $380(1274)$ & $6-8(6.6)$ & $M / F$ & $\begin{array}{l}380(1274) \\
\text { Delton® } \\
\text { divided } \\
\text { according } \\
\text { to the risk } \\
\text { of caries }\end{array}$ & & & & $\begin{array}{l}\text { Children } \\
\text { recruited in a } \\
\text { private clinic } \\
\text { of Athens had } \\
\text { to have at } \\
\text { least a first } \\
\text { permanent } \\
\text { molar } \\
\text { completely } \\
\text { erupted }\end{array}$ & $\begin{array}{l}\text { Interproximal } \\
\mathrm{RX} \text { if there } \\
\text { was an } \\
\text { indication for } \\
\text { diagnosis of } \\
\text { approximal } \\
\text { or occlusal } \\
\text { dentin lesion }\end{array}$ & $\begin{array}{l}\text { Every } 6 \\
\text { months } \\
\text { up to } 36 \\
\text { months }\end{array}$ \\
\hline Liu et al. ${ }^{17}$ & RCT & $50 \mathrm{I}(50 \mathrm{I})$ & $\operatorname{DNC}(9,1)$ & $M / F$ & $\begin{array}{l}\text { I24 (124) } \\
\text { Sealing } \\
\text { Clinpro® } \\
\text { (only one } \\
\text { application) }\end{array}$ & $\begin{array}{l}124(124) \\
\text { Varnish NaF } \\
5 \% \text {-Duraphat }{ }^{\circledR} \\
\text { (2x/year) }\end{array}$ & $\begin{array}{l}\text { I25 (I25) } \\
\text { Silver } \\
\text { diamino } \\
\text { fluoride } \\
\text { solution } \\
38 \%- \\
\text { saforide } ® \\
\text { (Ix/year) }\end{array}$ & $\begin{array}{l}\text { I28 (128) } \\
\text { Control- } \\
\text { annual } \\
\text { water } \\
\text { application }\end{array}$ & $\begin{array}{l}\text { Kids from } \\
\text { a suburb of } \\
\text { southern } \\
\text { China, with } \\
\text { deep grooves } \\
\text { or with initial } \\
\text { carious lesion } \\
\text { diagnosis }\end{array}$ & DNC & $\begin{array}{l}\text { Every } 6 \\
\text { months } \\
\text { up to } 24 \\
\text { months }\end{array}$ \\
\hline $\begin{array}{l}\text { Espelid et } \\
\text { al. }{ }^{13}\end{array}$ & $\begin{array}{l}\text { CCT- } \\
\text { split- } \\
\text { mouth }\end{array}$ & $43(98)$ & $\begin{array}{l}5,5-11 \\
(7,8)\end{array}$ & $\mathrm{DNC}$ & $\begin{array}{l}43(49) \\
\text { Vitremer }\end{array}$ & $\begin{array}{l}43 \text { (49) Ketac- } \\
\text { Silver® }\end{array}$ & & & DNC & $\begin{array}{l}\text { The } \\
\text { restorations } \\
\text { were } \\
\text { examined } \\
\text { annually } \\
\text { through } \\
\text { bitewing } \\
\text { radiographs }\end{array}$ & $\begin{array}{l}\text { In } \\
6,12,24,36 \\
\text { months }\end{array}$ \\
\hline
\end{tabular}


Table Continued

\begin{tabular}{|c|c|c|c|c|c|c|c|c|c|c|c|}
\hline \multirow{2}{*}{$\begin{array}{l}\text { Author(s) } \\
\text { (Country, } \\
\text { year) }\end{array}$} & \multirow{2}{*}{$\begin{array}{l}\text { Type } \\
\text { of } \\
\text { study }\end{array}$} & \multicolumn{3}{|l|}{ Sample } & \multicolumn{4}{|c|}{ Intervention groups } & \multirow{2}{*}{$\begin{array}{l}\text { Inclusion } \\
\text { criteria }\end{array}$} & \multirow{2}{*}{$\begin{array}{l}\text { Measure } \\
\text { of results } \\
\text { (bitewing } \\
\text { radiogra- } \\
\text { phy) }\end{array}$} & \multirow{2}{*}{$\begin{array}{l}\text { Return } \\
\text { visits/ Time } \\
\text { of monito- } \\
\text { ring }\end{array}$} \\
\hline & & $\begin{array}{l}\text { Individual } \\
\text { (Teeth) }\end{array}$ & $\begin{array}{l}\text { Age } \\
\text { (average) }\end{array}$ & Sex & $\begin{array}{l}\text { Group I } \\
\text { Individual } \\
\text { (Teeth) }\end{array}$ & $\begin{array}{l}\text { Group } 2 \\
\text { Individual } \\
\text { (Teeth) }\end{array}$ & $\begin{array}{l}\text { Group } 3 \\
\text { Individual } \\
\text { (Teeth) }\end{array}$ & $\begin{array}{l}\text { Group } 4 \\
\text { Individual } \\
\text { (Teeth) }\end{array}$ & & & \\
\hline $\begin{array}{l}\text { Ekstrand } \\
\text { et al. }{ }^{15}\end{array}$ & $\begin{array}{l}\text { CCT- } \\
\text { split- } \\
\text { mouth }\end{array}$ & $48(48)$ & $5-8(7.2)$ & DNC & $\begin{array}{l}48 \text { (DNC) } \\
\text { infiltration } \\
\text { resin } \\
\text { followed by } \\
\text { Duraphat } \circledast \\
\text { (reapplied } \\
\text { every } 6 \\
\text { months) }\end{array}$ & $\begin{array}{l}48 \text { (DNC) } \\
\text { Duraphat } ® \\
\text { (reapplied } \\
\text { every } 6 \\
\text { months) }\end{array}$ & & & $\begin{array}{l}\text { Children } \\
\text { who used the } \\
\text { Nuuk public } \\
\text { health service } \\
\text { had to have } \\
\text { two proximal } \\
\text { lesions in } \\
\text { enamel or } \\
\text { outer half of } \\
\text { the dentin } \\
\text { in deciduous } \\
\text { molars }\end{array}$ & $\begin{array}{l}\text { Positioners } \\
\text { were } \\
\text { used for } \\
\text { radiographs } \\
\text { takings } \\
\text { to all be } \\
\text { standardized, } \\
\text { of both sides } \\
\text { of the mouth. }\end{array}$ & $\begin{array}{l}\text { Every } 6 \\
\text { months } \\
\text { up to } 12 \\
\text { months }\end{array}$ \\
\hline $\begin{array}{l}\text { Bhuridej et } \\
\text { al. }{ }^{19}\end{array}$ & CCT & $\begin{array}{l}308 \\
\text { (DNC) }\end{array}$ & DNC (6) & $M / F$ & $\begin{array}{l}\text { I23 (I23) } \\
\text { Sealed } \\
\text { molars }\end{array}$ & $\begin{array}{l}\text { I85 (185) } \\
\text { Non-sealed } \\
\text { molars }\end{array}$ & & & $\begin{array}{l}\text { Children } \\
\text { who had } \\
\text { completed } 6 \\
\text { years of age } \\
\text { in 1996, who } \\
\text { were enrolled } \\
\text { in the lowa } \\
\text { Medicaid } \\
\text { program, } \\
\text { from } 1996 \\
\text { to } 2000 \text { and } \\
\text { who used } \\
\text { the services } \\
\text { routinely. }\end{array}$ & $\begin{array}{l}\text { A complete } \\
\text { series of } \\
\text { intraoral } \\
\text { radiographs } \\
\text { was } \\
\text { performed in } \\
\text { the first visit } \\
\text { and in the } \\
\text { return visits. }\end{array}$ & $\begin{array}{l}\text { Between } \\
1996 \text { and } \\
2000 \text { (the } \\
\text { period of } \\
\text { time betwe- } \\
\text { en returns } \\
\text { was not pre- } \\
\text { determined), } \\
\text { that is, } 48 \\
\text { months of } \\
\text { monitoring }\end{array}$ \\
\hline $\begin{array}{l}\text { Foley et } \\
\text { al. }^{14}\end{array}$ & $\begin{array}{l}\text { CCT- } \\
\text { split- } \\
\text { mouth }\end{array}$ & $44(120)$ & $\begin{array}{l}3.7-9.5 \\
(6,8)\end{array}$ & $M / F$ & $\begin{array}{l}\text { Partial } \\
\text { caries } \\
\text { removal } \\
\text { (PCR) and } \\
\text { Cooper } \\
\text { Cement } \AA \\
(B C C) \times \\
\text { PCR and } \\
\text { Chemfil } \\
\text { Superior }{ }^{\circledR} \\
(\text { GIC) }\end{array}$ & $\begin{array}{l}\mathrm{PCR} \text { and } \mathrm{BCC} \\
\mathrm{X} \text { Complete } \\
\text { removal of } \\
\text { caries and } \\
\text { conventional } \\
\text { restoration } \\
(\mathrm{CR})\end{array}$ & $\begin{array}{l}\text { PCR and } \\
\mathrm{GIC} \times \mathrm{CR}\end{array}$ & & $\begin{array}{l}\text { Children, } \\
\text { whose } \\
\text { carious } \\
\text { deciduous } \\
\text { molars were } \\
\text { asymptomatic, } \\
\text { not restored } \\
\text { and without } \\
\text { pulpal } \\
\text { involvement, } \\
\text { who were } \\
\text { seen routinely } \\
\text { in Odontol } \\
\text { Department. } \\
\text { Ped of the } \\
\text { Hospital in } \\
\text { Dundee as } \\
\text { long as the } \\
\text { teeth were } \\
\text { in different } \\
\text { quadrants }\end{array}$ & $\begin{array}{l}\text { Bitewing } \\
\text { x-rays were } \\
\text { performed at } \\
\text { the beginning } \\
\text { of the study } \\
\text { and in the } \\
\text { return } \\
\text { visit, from } \\
\text { I } 2 \text { to } 24 \\
\text { months, using } \\
\text { standardized } \\
\text { methods. }\end{array}$ & $\begin{array}{l}\text { Every } 6 \\
\text { months } \\
\text { up to } 24 \\
\text { months }\end{array}$ \\
\hline
\end{tabular}

Citation: Paz SH, Paz DDS, Brizon VSC, et al. Effectiveness of sealants on incipient cavitaded lesions.J Dent Health Oral Disord Ther. 2018;9(3): 179-184. 


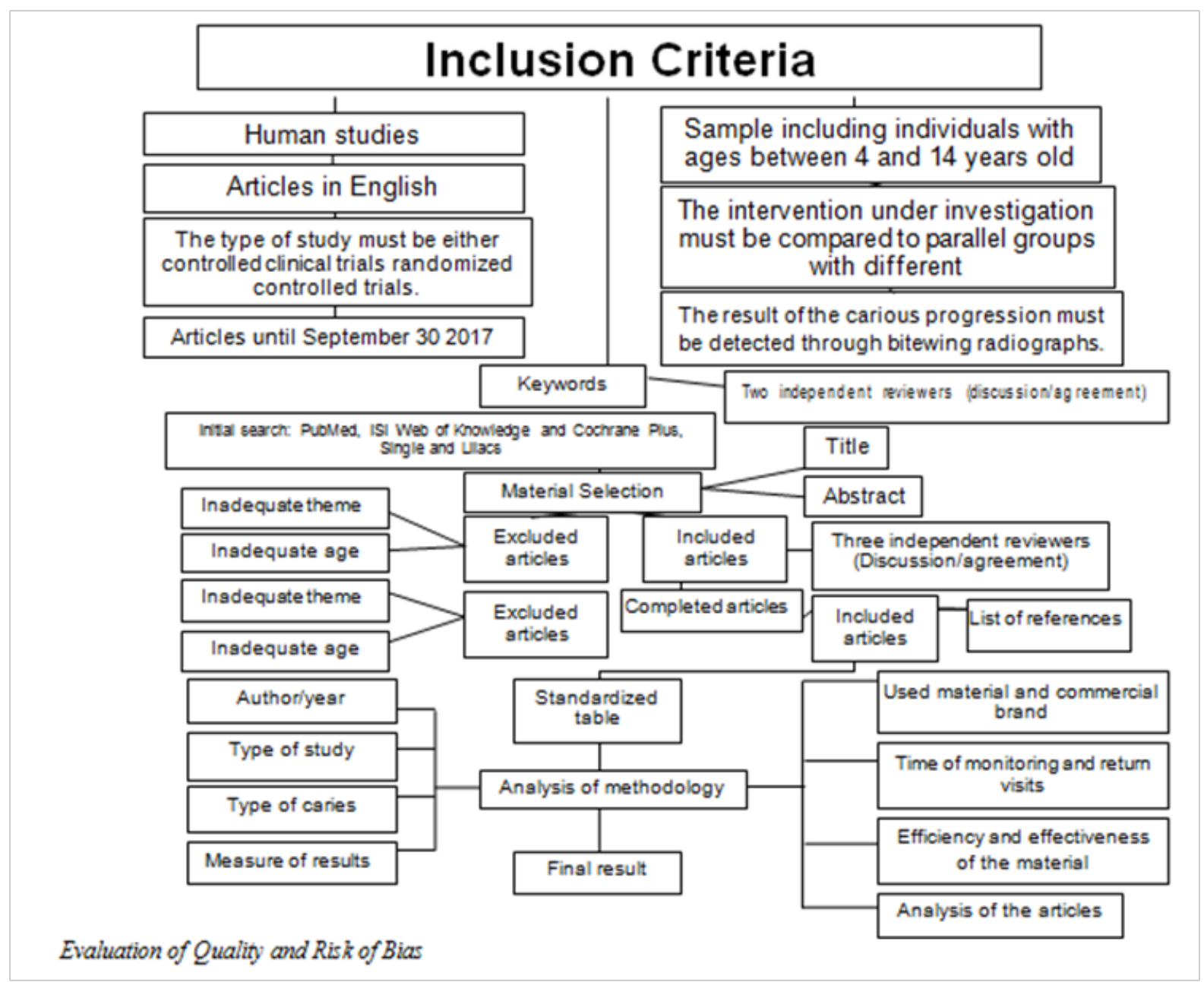

Figure I Flowchart of the study's methodology.

\section{Results}

In a total of 474 potentially relevant records found in the databases, 18 articles were duplicates and, thus, excluded. Then, the studies' abstracts were read. A total of 441 references were excluded based on titles and/or abstracts and 15 were selected for analysis of complete texts, of which 7 were included in this systematic review. Among the articles included, we observed a diversity of countries that worked with the theme proposed in this review, despite all the studies found having been written in English. All studies had clinical follow-up and monitoring of the data in a longitudinal manner. In addition, three studies involved split-mouth design studies. ${ }^{13-15}$ In relation to the type of carious lesions studied, two papers have focused their research on occlusal carries, ${ }^{16.17}$ others in proximal caries, ${ }^{13-15}$ two other studies studied occlusal and approximal caries ${ }^{14-18}$ and only one study did not disclose the type of caries studied. ${ }^{19}$ For the purpose of measuring results, a study used digital x-rays ${ }^{16}$ other studies used bitewing radiographs ${ }^{13-19}$ and only one article does not mention the use of $\mathrm{x}$-rays for diagnosing. ${ }^{17}$ Among the materials used for the research are: sealant, ${ }^{18,19}$ resin-modified glass ionomer, ${ }^{13,16}$ resin sealant, ${ }^{17}$ fluoride varnish, ${ }^{13,16,17}$ silver diamine fluoride SFD solution, ${ }^{17}$ silver-reinforced glass ionomer, ${ }^{13}$ black copper cement, conventional glass ionomer and conventional restorative material. ${ }^{14}$ Regarding the time of monitoring until the end of the treatment, only one study took four years, ${ }^{19}$ the other two were finished after 3 years of research, ${ }^{13,18}$ two more studies took 2 years to be completed, ${ }^{14,17}$ while the other two studies completed their work in the course of 1 year. ${ }^{15,16}$ Quality evaluation of the articles by the Quality assessment tool for quantitative studies had $100 \%$ consensus for each item among the evaluators. The results revealed the following scenario: four papers obtained the final score 1, being classified as strong in methodology and at low risk of bias, ${ }^{14-17}$ while the other studies were classified as moderate and with moderate bias. . $^{13,18,27}$

\section{Discussion}

The result of the evaluation of the articles included via the Quality assessment tool for quantitative studies reflected the complexity in managing the multiple variables present in the surveys and the risk of bias. Among the criteria for assessing the quality of the studies, "sample selection" is analyzed. None of the 7 studies included in this systematic review obtained strong classification for this criterion. In most of them, the selection was done systematically from a clinic or a neighborhood or even schools or day care centers, in addition to the information that the percent of individuals who agreed to participate in the study was greater than $80 \%$. A study obtained weak quantification in the criterion "selection bias" because the study did not mention 
either where or how the sample of the study was allocated. ${ }^{13}$ However, all the selected studies involved controlled clinical trials or randomized controlled trials, being classified as strong for the criterion "type of study". The correct randomization allows an individual to have the same chances to participate in the control group and in the intervention group. ${ }^{20}$ As for the criterion "blinding", its classification was considered strong for two researches, $;^{14,15}$ besides the blinding of the examiners, the samples were also blinded. Three researches were considered moderate for this criterion. In these, examiners were blinded, but the article did not inform regarding the elements of the sample..$^{13-18}$ In another study, the examiners were responsible for the evaluation of the medical records of the participants of the study, so this article was rated as weak for this criterion. ${ }^{19}$ Another study was also considered weak for the blinding criterion, since there was no blinding of the examiners and there is no data about the blinding of the samples..$^{18}$ To avoid bias in the results, i.e., so that the results do not suffer influences from the examiners and neither from the participants of the study, the blinding of the study is recommended. Its importance is considerable for the reliability of the results. ${ }^{21-23}$ For the monitoring of the cases, it was necessary to compare radiographic images and/or an evaluation of the clinical examinations based on parameters and indices predefined among the examiners; all studies were classified as strong for the data collection method, confirming the reliability and reproducibility of the data collected and showing special attention destined to the results of the studies. Furthermore, none of the studies considered the symptoms reported by the target population, only the clinical and/or radiographic examinations obtained by the examiners based on pre-established criteria. Monitoring is a relevant factor, since it ensures that clinically significant outcomes as well as adverse effects expected for the research occur and are detected. ${ }^{22,24}$ All studies that evaluated proximal carious lesions used bitewing radiographs every 6 months. ${ }^{13-18}$ In addition to being a low cost and easy to handle technique, bitewing radiography, when associated with clinical examination, enables greater accuracy in the diagnosis of proximal caries. ${ }^{25}$ Only one study did not disclose the treatment protocol and the description of the techniques used for the application of preventive methods. ${ }^{19}$ Among the materials used for research are the conventional glass ionomer cements $\left(\right.$ Chemfil Superior $\left.{ }^{\mathbb{B}}\right)$, resinmodified ionomer cements $\left(\right.$ Vitremer $^{\circledR}$, Delton ${ }^{\circledR}$ and Clinpro ${ }^{\circledR}$ ), silver reinforced glass ionomer cements (Ketac-Silver $\left.{ }^{\mathbb{B}}\right)$, black copper cement $\left(\right.$ Cooper Cement $\left.{ }^{\mathbb{R}}\right)$, fluoride varnish $\left(\right.$ Duraphat $\left.{ }^{\mathbb{R}}\right)$, and fluoride solution $\left(\right.$ Saforide $\left.^{\circledR}\right)$. These materials are important for public health, as dental service advocates besides clinical care and being active in the community, epidemiological surveys, preventive actions, education and promotion of oral health. ${ }^{26}$ Despite the studies having different research protocols in the comparison of the various preventive materials, most researches presented more effective results for the use of sealants. ${ }^{13-19}$ Two of these studies ${ }^{13-16}$ showed greater effectiveness in the use of resin-modified ionomer cement - Vitremer ${ }^{\circledR}$ when compared with another sealant (ketac-Silver $\left.{ }^{\mathbb{R}}\right)$ and when compared to control groups and fluoride varnish $\left(\right.$ Duraphat $\left.^{\mathbb{B}}\right)$, confirming its excellent properties as an anticariogenic agent, for being one of the cements which most release fluoride and for absorbing fluoride from topical applications, for an enhanced work time, for being photoactivated, plus the ability to significantly prevent microleakage. However, regardless of the material and technique used, the adhesion to the surface of the enamel and being a mechanical barrier between the tooth and the microbiota are the main preventive functions of sealants. ${ }^{27}$ Nevertheless, in a meta-analysis the efficiency of pit and fissure sealants in comparison to fluoride varnish was analyzed, and a superiority of sealants was evidenced, concluding that the benefits must consider locally and individually. ${ }^{28}$ Some studies involved splitmouth design studies, in which a same individual exhibited both the intervention and the control. ${ }^{13-15}$ Split-mouth studies are very well accepted because the sample is subject to the same conditions in terms of risk of cavities. On the other hand, the recruitment of individuals with similar conditions to allow comparison can be more difficult, justifying the smaller sample sizes. ${ }^{20}$ In relation to the criterion "loss of sample", four surveys were considered strong, meaning that the abandonments or losses were reported in number terms and the percentage of the sample that completed the study exceeded $80 \% .{ }^{15-18}$ The other surveys were considered moderate for this criterion. ${ }^{13-19}$ A study presented the reasons for the losses that occurred in the course of the study by means of tables, but showed a survival rate of about $72 \%$ of the sample until the end of the research, justifying its moderate classification. ${ }^{13}$ Other study involved a research of charts of patients of a particular clinic, therefore it did not exhibit loss or abandonment of the sample. ${ }^{19}$ Another study disclosed the reasons for the sample losses, but its survival rate reached only $65.90 \%$, confirming its classification. ${ }^{14}$ The favorable outcome regarding the loss of the sample can be a result of the time period elapsed until the end of the study not being too long, since the studies took between 12 and 48 months of research. Finally, the results suggest that the majority of the studies showed effectiveness of the techniques used for application of sealants with minimal removal of carious tissue and effectiveness of the results obtained with the use of sealing materials. In addition, the sealing technique in cavitated carious lesions without pulpal involvement appears to be effective in the short and medium terms. It becomes, therefore, relevant to research more controlled studies on the effects of caries control, with longer monitoring periods to increase this evidence.

\section{Acknowledgments}

None.

\section{Conflict of interest}

The author declares that there is no conflict of interest.

\section{References}

1. Fejerskov O. Changing paradigms in concepts on dental caries: consequences for oral health care. Caries Res. 2004;38(3):182-191.

2. Marthaler TM. Changes in dental caries 1953-2003. Caries Res. 2004;38(3):173-81.

3. Peres MA, Latorre MRDO, Sheiham A, et al. Determinantes sociais e biológicos da cárie dentária em crianças de 6 anos de idade: um estudo transversal aninhado numa coorte de nascidos vivos no Sul do Brasil. Rev Bras Epidemiol. 2003;6:293-306.

4. Buss PM, Filho AP. A Saúde e seus Determinantes Sociais. Physis Revista de Saúde Coletiva. 2007;17(1):77-93.

5. Frias AC, Antunes JLF, Junqueira SR. Determinantes individuais e contextuais da prevalência de cárie dentária não tratada no Brasil. Rev Panam Salud Publica. 2007;22:279-85.

6. Narvai PC, Frazão P, Roncalli AG. Cárie dentária no Brasil: declínio, polarização, iniqüidade e exclusão social. Rev Panam Salud Publica. 2006;19(6):385-393.

7. Pavinato LCB, Imparato JCP. Efetividade do selamento de fossas e fissuras na prevenção da doença cárie: análise crítica da literatura. Odonto. 2012;20(40):23-30. 
8. Schwendicke F, Jäger AM, Paris S, et al. Treating pit-and-fissure caries: a systematic review and network meta-analysis. $J$ Dent Res. 2015;94(4):522-33.

9. Hickel R, Peschke A, Tyas M. FDI World Dental Federation: clinical criteria for the evaluation of direct and indirect restorations-update and clinical examples. Clin Oral Investig. 2010;14(4):349-66.

10. Simonsen RJ. Pit and fissure sealant: review of the literature. Paediatr Dent. 2002;24(5):393-414.

11. Jackson N, Waters E. Guidelines for Systematic Reviews in Health Promotion and Public Health Taskforce. Criteria for the systematic review of health promotion and public health interventions. Health Promot Int. 2005;20(4):367-74.

12. Deeks JJ, Dinnes J, D'Amico R, et al. Evaluating non-randomised intervention studies. Health Technol Assess. 2003;7(27):1-173.

13. Espelid I, Tveit AB, Tornes KH. Clinical behaviour of glass ionomer restorations in primary teeth. $J$ Dent. 1999;27(6):437-442.

14. Foley J, Evans D, Blackwell A. Partial caries removal and cariostatic materials in carious primary molar teeth: a randomised controlled clinical trial. Br Dent J. 2004;197(11):697-701.

15. Ekstrand KR, Bakhshandeh A, Martignon S. Treatment of proximal superficial caries lesions on primary molar teeth with resin infiltration and fluoride varnish versus fluoride varnish only: efficacy after 1 year. Caries Res. 2010;44(1):41-6.

16. Flório FM, Pereira AC, Meneghim MC. Evaluation of non-invasive treatment applied to occlusal surfaces. ASDC J Dent Child. 2001;68(56):326-301.

17. Liu BY, Lo EC, Chu CH. Randomized trial on fluorides and sealants for fissure caries prevention. $J$ Dent Res. 2012;91(8):753-8.

18. Oulis CJ, Berdouses ED. Fissure sealant retention and caries development after resealing on first permanent molars of children with low, moderate and high caries risk. Eur Arch Paediatr Dent. 2009;10(4):211-7.
19. Bhuridej P, Damiano PC, Kuthy RA. Natural history of treatment outcomes of permanent first molars: a study of sealant effectiveness. $J$ Am Dent Assoc. 2005;136(9):1265-1272.

20. Ammari MM, Soviero VM, da Silva Fidalgo TK. Is non-cavitated proximal lesion sealing an effective method for caries control in primary and permanent teeth? A systematic review and meta-analysis. J Dent. 2014;42(10):1217-27.

21. Jadad AR, Moore RA, Carroll D. Assessing the quality of reports of randomized clinical trials: is blinding necessary?. Control Clin Trials. 1996;17(1):1-12.

22. Carvalho APV, Silva V, Grande AJ. Avaliação do risco de viés de ensaios clínicos randomizados pela ferramenta da colaboração Cochrane. Diagnóstico e Tratamento. 2013;18(1):38-44.

23. Kahan BC, Rehal S, Cro S. Blinded Outcome Assessment Was Infrequently Used and Poorly Reported in Open Trials. PloS One. 2015;10:e131926.

24. Tura BR, Souza e Silva NA, Pereira BB. Avaliação crítica e limitações dos ensaios clínicos. Revista Brasileira de Cardiologia. 2003;16:110-123.

25. Silva AVC, Pereira JRD, Beatrice LCS. Diagnóstico de lesão de cárie proximal por imagem: Revisão Sistemática. Odontologia ClínicoCientifica. 2012;11:17-24.

26. Antunes JLF, Narvai PC. Políticas de saúde bucal no Brasil e seu impacto sobre as desigualdades em saúde. Rev Saude Publica. 2010;44:360-5.

27. Kim JW, Jang KT, Lee SH. Effect of curing method and curing time on the microhardness and wear of pit and fissure sealants. Dent Mater. 2002; 18:120-127.

28. Hiiri A, Ahovuo-Saloranta A, Nordblad A. Pit and fissure sealants versus fluoride varnishes for preventing dental decay in children and adolescents. Cochrane Database Syst Rev. 2006;18(1): CD003067. 